\title{
Histogenetic Processes Leading to the Laminated Neocortex: Migration Is Only a Part of the Story
}

\author{
V.S. Caviness ${ }^{a}$ P.G. Bhide ${ }^{a}$ R.S. Nowakowski ${ }^{b}$ \\ a Department of Neurology, Massachusetts General Hospital, Boston, Mass., and bepartment of Neuroscience and \\ Cell Biology, UMDNJ-RWJ Medical School, Piscataway, N.J., USA
}

\section{Key Words}

Neocortical histogenesis $\cdot$ Neuronal migration $\cdot$ Cell

position $\cdot$ Cortical pattern $\cdot$ Cell death

\begin{abstract}
The principal events of neocortical histogenesis were anticipated by work published prior to the 20th century. These were neuronal proliferation and migration and the complex events of cortical pattern formation leading to a laminated architecture where each layer is dominated by a principal neuronal class. Work that has followed has extended the knowledge of the workings of the proliferative epithelium, cellular mechanisms of migration and events through which cells are winnowed and then differentiate once their postmigratory positions are established. Work yet ahead will emphasize mechanisms that coordinate the molecular events that integrate proliferation and cell class specification in relation to the final neocortical neural system map.
\end{abstract}

Copyright $\odot 2008$ S. Karger AG, Basel

The neocortex is the dominant structure of the mammalian cerebral surface, sharing only limited portions of the ventral and medial surfaces with the much smaller archicortical and paleocortical structures [Brodmann,
1909; von Economo and Koskinas, 1925; Zilles, 1990]. It has a distinctive 6-layered architecture continuous throughout with each layer dominated by a principal class of neuron. Regional variations in the stratification patterns, corresponding to functional architectonic subdivisions, are distinguished by characteristic widths, patterns of cell arrangements and density and tinctorial properties of the cells of each lamina. These diverse features, which characterize the mature cortex and are indispensable to its operations, have a complex histogenetic history that reflects a dramatic, precisely orchestrated sequence of cellular events implemented by complex signaling and molecular mechanisms. In the largest mammals, these events, coordinated over months, regulate the origin, qualities and disposition of literally millions of neurons [Sidman and Rakic, 1982]. We review in the following salient highlights of these cellular events as our understanding of them has emerged in the course of more than a century of investigations. We begin with several brief historical notes treating work from late in the 19th century. We view these contributions as the origin of investigational themes for the century that was to come. We will continue with a review of highlights of work following these investigational themes. These are the origin of the neocortical projection neurons in the periventricular proliferative epithelium, their migration from place of

\section{KARGER}

두 2008 S. Karger AG, Basel

Fax +41613061234 E-Mail karger@karger.ch www.karger.com
Accessible online at: www.karger.com/dne
Verne S. Caviness, $\mathrm{MD}, \mathrm{PhD}$

Department of Neurology

Massachusetts General Hospital, 55 Fruit Street, VBK-901

Boston, MA 02114 (USA)

Tel. +1 617726 1813, Fax +1 617726 2353, E-Mail caviness@helix.mgh.harvard.edu 
origin to cortex, the events within the cortex that eventuate in their final relative positions and finally the winnowing process that culminates in the final roster of neurons.

\section{Historical Notes}

A critical and organizing insight, setting the stage of the developmental cell biological discoveries to come, was achieved late in the 19th century by His $[1889,1904]$. Specifically he was able to infer from general cell stains that neurons of the neocortex arise not in situ within the cortex itself but rather in the course of a sustained process of cell proliferation in an epithelium lining the ventricular cavities in the depths of the cerebral vesicle. It was apparent to him that young neurons must then migrate across the full width of the cerebral wall from the place of origin to their eventual destiny in the neocortex at the surface of the hemisphere. A startling insight relating time of origin to ultimate radial disposition in the cortex was then provided by the Golgi analysis of embryonic brains by von Koelliker [1896], who realized that the maturation and origin sequence of postmigratory neurons in the cortical anlage could be read from the relative degree of elaboration of apical and then basal dendritic arbors (fig. 1). Because this important insight is not widely appreciated, we quote here from his original text:

'Die Pyramidalenzellen anlangend, so gab dieser Embryo den wichtigen Aufschluss, dass dieselben von aussen nach der Tiefe sich entwickeln. Es fanden sich nämlich ... immer noch die allerjüngsten bei dem vier- und siebenmonatlichen Embryo gefundenen Stadien in grösster Zahl in der alleräussersten Lage der Zellenschicht, dicht am Stratum zonale' [von Koelliker, 1896].

To paraphrase, postmitotic neurons migrate in the order in which they arise to become assembled in an insideto-outside laminar order. Implicit here is the realization that proliferative succession corresponds to laminar class origin succession with the earliest formed assigned to the deepest and successively later formed to successively more superficial layers, that is the 'inside-out' pattern of succession established by experimental DNA-labeling methods more than half a century later [Sidman et al., 1959; Angevine and Sidman, 1961].

Also in the epoch of His, it was recognized that among the heritable microcephalies [Vogt, 1895; Cunningham, 1895] (fig. 2) were disorders where the neocortex is reduced in width. The laminar order is preserved but the populations of the outer layers are greatly reduced relative to those of the deeper layers [Hammarberg, 1895]

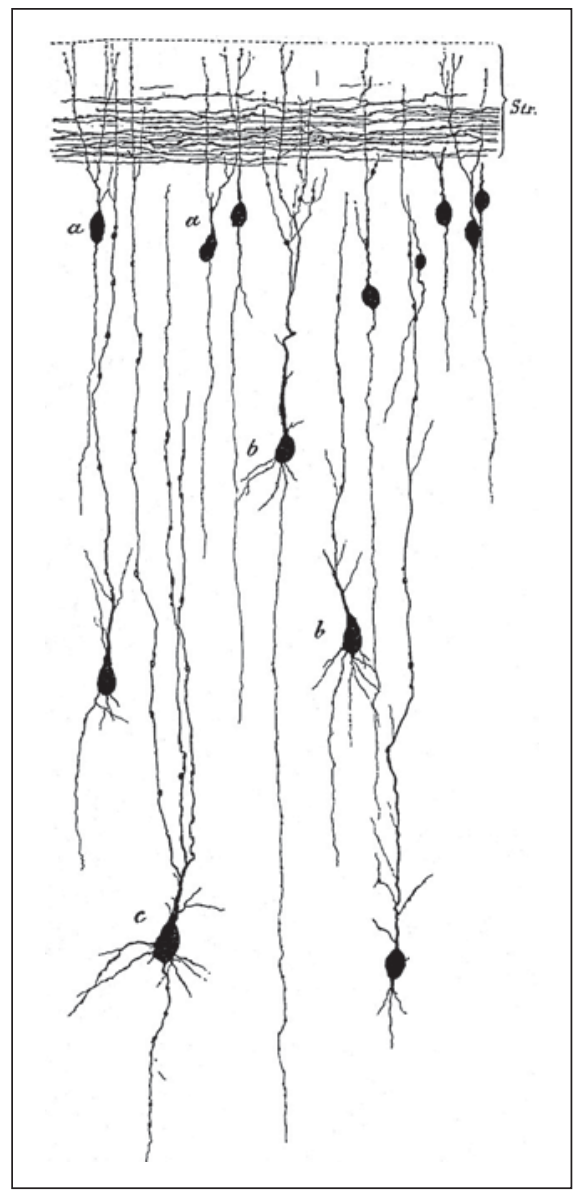

Fig. 1. Golgi impregnation of late first-trimester embryo. The pyramidal cells from deep to superficial illustrate an orderly differentiation sequence where those in the deepest level have elaborated apical and basal dendritic systems and the superficial ones only early elaboration of the apical systems [von Koelliker, 1896].

(fig. 3). That is, single-gene disorders associated with profound reduction of neuron formation may preferentially have an impact upon the generation of the outer, that is the later specified and formed, classes of neurons. In retrospect we may infer that in these brains, the proper neuronal classes in fact are formed, migrate properly and become positioned properly in laminae with a pattern of subsequent winnowing that yields region-specific architectonic patterns (fig. 3). This pattern is now recognized also to be characteristic of disordered regulation of the proliferative process itself as a consequence of mutation of a diverse set of specific gene mutations in mice [Monuki et al., 2001; Roy et al., 2004; Yun et al., 2004].

Thus, insights from these early investigations essentially laid out the salient themes of investigations to fol- 
Fig. 2. Images of microcephalics approximately 8 (1), about 20 (2) and around 5060 years old $(3,4)$ by the estimate of the author. Basal images of the brain $(5,6)$ are from subjects 3 and 1 [Cunningham, 1895].

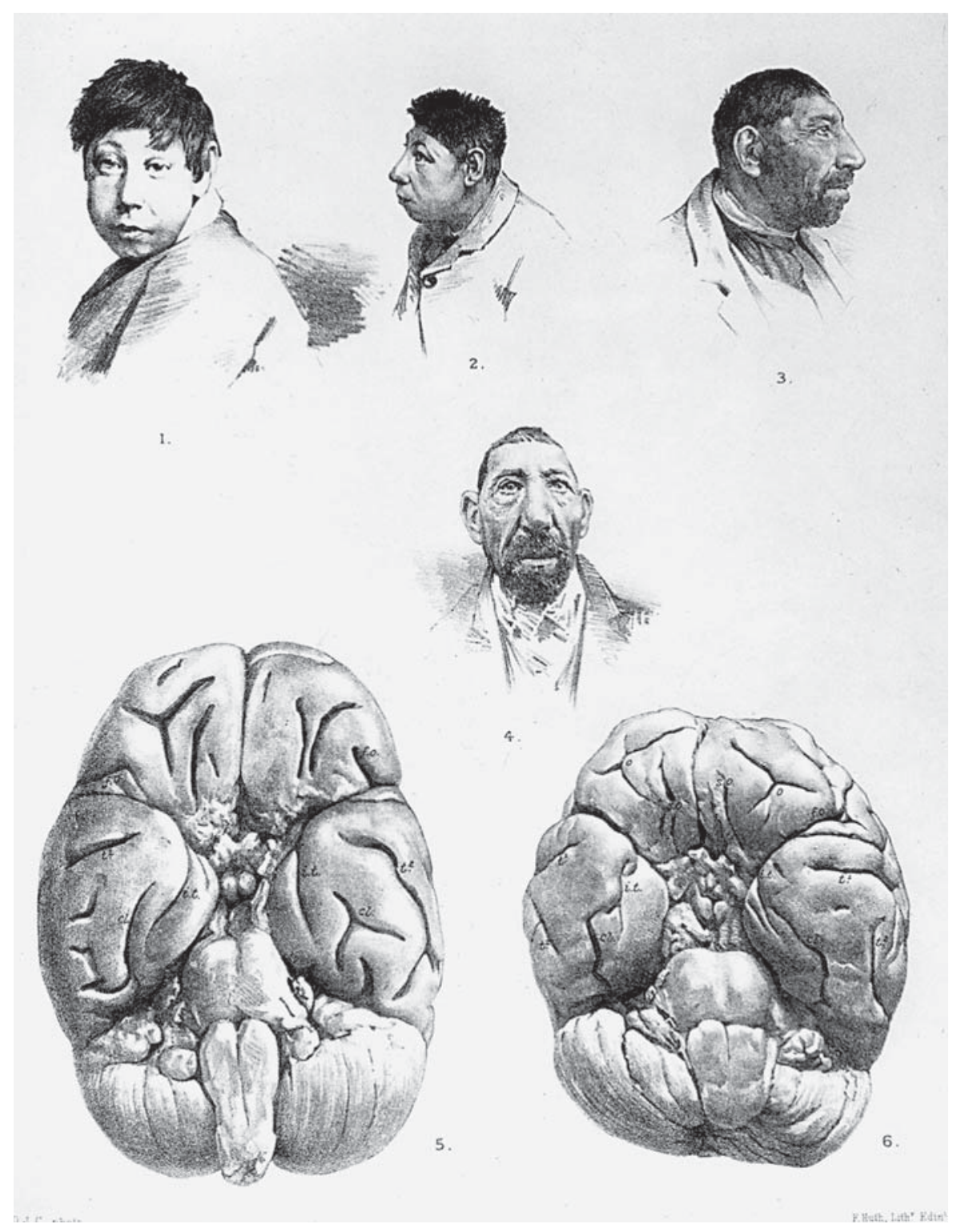

low over the century focused upon the sequence and scheduling of histogenetic events leading to the elaboration of neocortical cell pattern. These have been the coordinate events of cell production and cell class specification during the proliferative phase, migration, laminar distribution and arrival at final populations and arrangement. Investigations going forward over the past century have greatly illuminated the cell biological and, to a more limited extent, the molecular mechanisms through which the final architectonic pattern of the neocortex is achieved. This extensive body of knowledge will be treated here only in terms of the selected 'chapters', which have had our personal attention over the years. These include the proliferative process itself, certain aspects of migration and the postmigratory events of positioning and cell winnowing.

\section{Neuron Proliferation as Determinant of Architectonic Pattern}

The projection neurons of the neocortex arise exclusively in a proliferative epithelium lining the ventricular margin of the embryonic cerebral ventricles [Boulder 
Fig. 3. Transverse sections stained with methylene blue from normal cortex (a) and cortex from gravely cognitively impaired microcephalic subjects (b). The Betz cells readily recognized in columns 3 and 4, respectively, identify the corresponding pre-Rolandic gyrus in the normal and microcephalic subjects. The other panels illustrate the corresponding regions of frontal, parietal and occipital association cortical regions. The important generalizations to take from these comparisons is that the microcephalic cortex is laminated with the appropriate radial order by readily recognized classes corresponding to those in the normal subject but that there is marked attenuation of the most superficial layers in the microcephalic brains [Hammarberg, 1895].
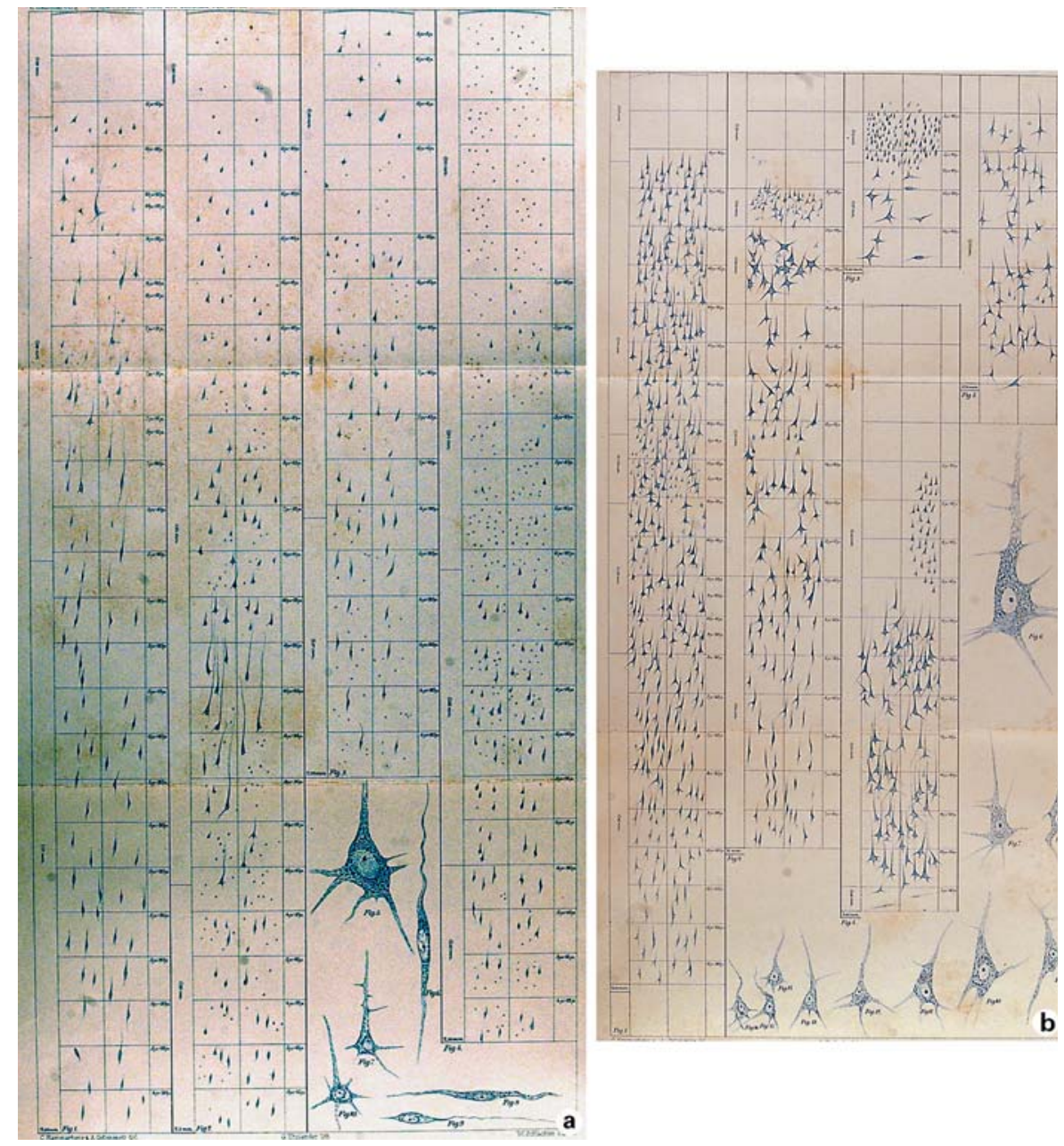

Committee, 1970; Takahashi et al., 1995a; Kriegstein, 2005]. It was the work of Sauer $[1935,1936]$ that provided the insight that the epithelium was pseudostratified and that the configuration of the cell changed systematically from an elongate form with abventricular nucleus in the $S$ phase to a rounded form with a nucleus located at the ventricular margin in the $\mathrm{M}$ phase of the cell cycle (pseudostratified ventricular epithelium, PVE; fig. 4). The initial insight of von Koelliker [1896] that neurons arise in an inside-out order with respect to laminar disposition was abundantly confirmed and amplified in its detail more than half a century later by $S$ phase pulse labeling methods [Sidman et al., 1959; Angevine and Sidman, 1961; Caviness, 1982]. That is, for any given area of the neocortex the neurons are formed in the same overlapping 'inside-out' layer VI to layer II succession. However, neurons of the same class are not produced simultaneously; instead, the succession is initiated rostrolaterally at the margin of the striatal PVE and propagates caudomedially [Sidman et al., 1959b; Angevine and Sidman, 1961; Caviness, 1982; Smart and Smart, 1982; Bayer and Altman, 1991] along what is known as the transverse neurogenetic gradient (TNG) [Bayer and Altman, 1991; Takahashi et al., 1995b; Miyama et al., 1997].

Events of the profoundest histogenetic significance occur in the course of the proliferative process and, one assumes, therefore, that these are coordinately linked to the proliferative mechanisms themselves. Foremost among these, it now appears, are the specification of neuronal class and of neocortical regions [Rakic, 1988]. Differentiation of laminar-class-specific cytological features continues as the postmitotic neuron settles in its appropriate laminar position and concurrently with the formation of specific connections. This inevitably raises the possibility that specification of these features is induced by interactions among neurons and axonal systems 


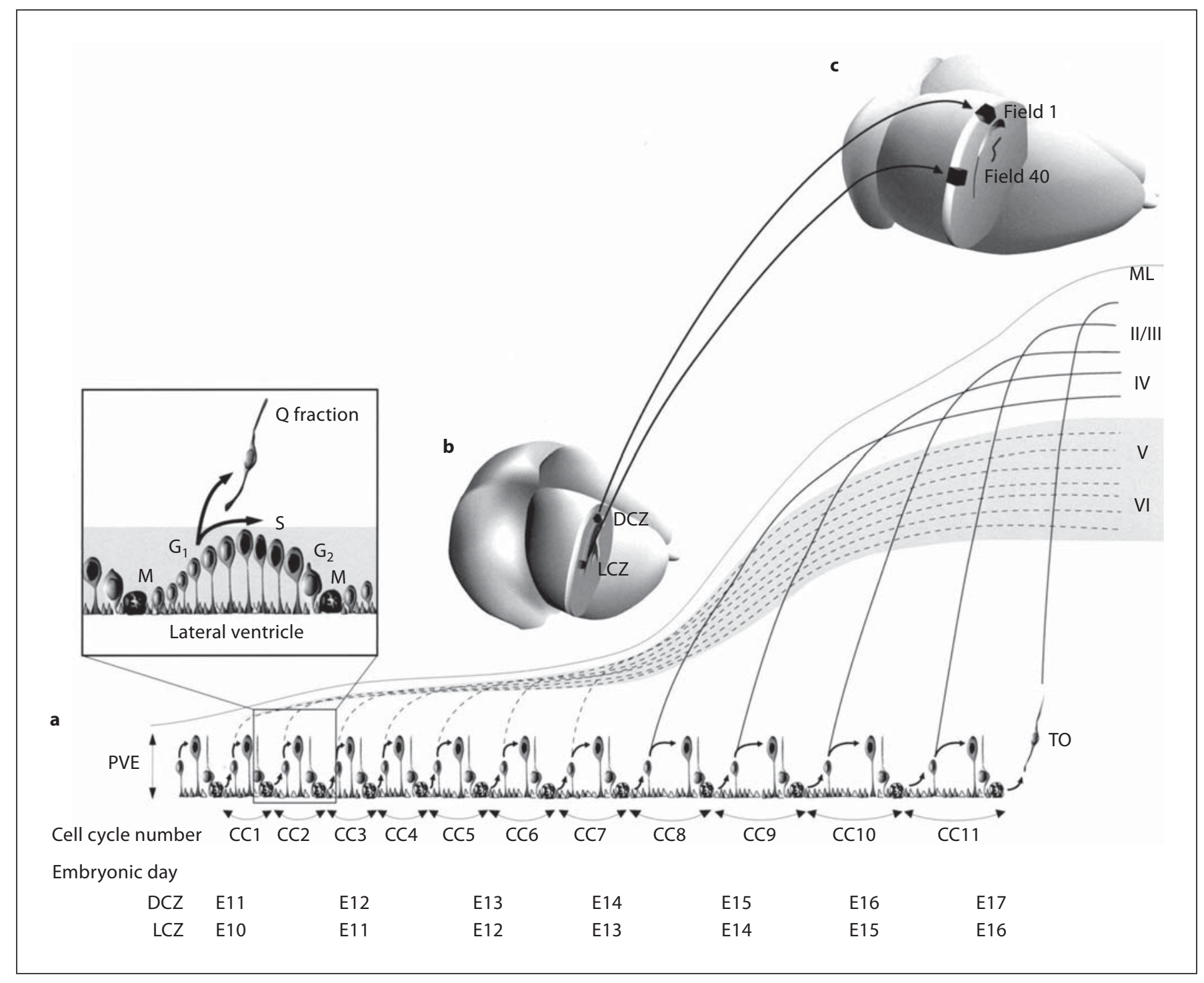

Fig. 4. Neuronogenesis in the PVE in relation to the inside-out pattern' of neocortical layer formation. a The founder proliferative populations and their progeny in both dorsomedial (DCZ) and lateral (LCZ) cortical zones of the PVE execute 11 cell cycles (CC1-CC11) in the course of the 6-day neuronogenetic interval, continuing from the 11th to the 17th embryonic day (E) in the DCZ and from the 10th to the 16th embryonic day in the LCZ. The cycle sequence is initiated earlier and remains advanced by about $24 \mathrm{~h}$ in the LCZ relative to the DCZ (note for each cell cycle a 24-hour difference in time of occurrence of corresponding cell cycles in the DCZ and LCZ). The first neurons to arise from either region of the PVE are destined for the deepest cortical layers (dashed curved lines connecting the PVE and layers VI and V), whereas progressively later forming neurons are destined for pro- gressively more superficial layers (solid curved lines connecting the PVE and layers IV and II/III). The daughter cells arising from cycle 11 are the terminal output (TO) of neuronogenesis. Curved arrows in the PVE show interkinetic nuclear migration through $G_{1}, S, G_{2}$ and $M$ phases of the cell cycle. $M L=$ Molecular layer. Interkinetic nuclear migration is shown for CC2 in the magnified view in the inset on the top left. A fraction of postmitotic cells (Q) leaves the PVE with each cycle and migrates toward the surface of the hemisphere as young neurons. b, c The DCZ and LCZ of the PVE of the embryonic cerebral hemisphere (b coronal cutaway) give rise (curved arrows connecting $\mathbf{b}$ and $\mathbf{c}$ ) to neurons destined, respectively, for fields 1 and 40 in the adult hemisphere (c coronal cutaway) [Takahashi et al., 1999]. 


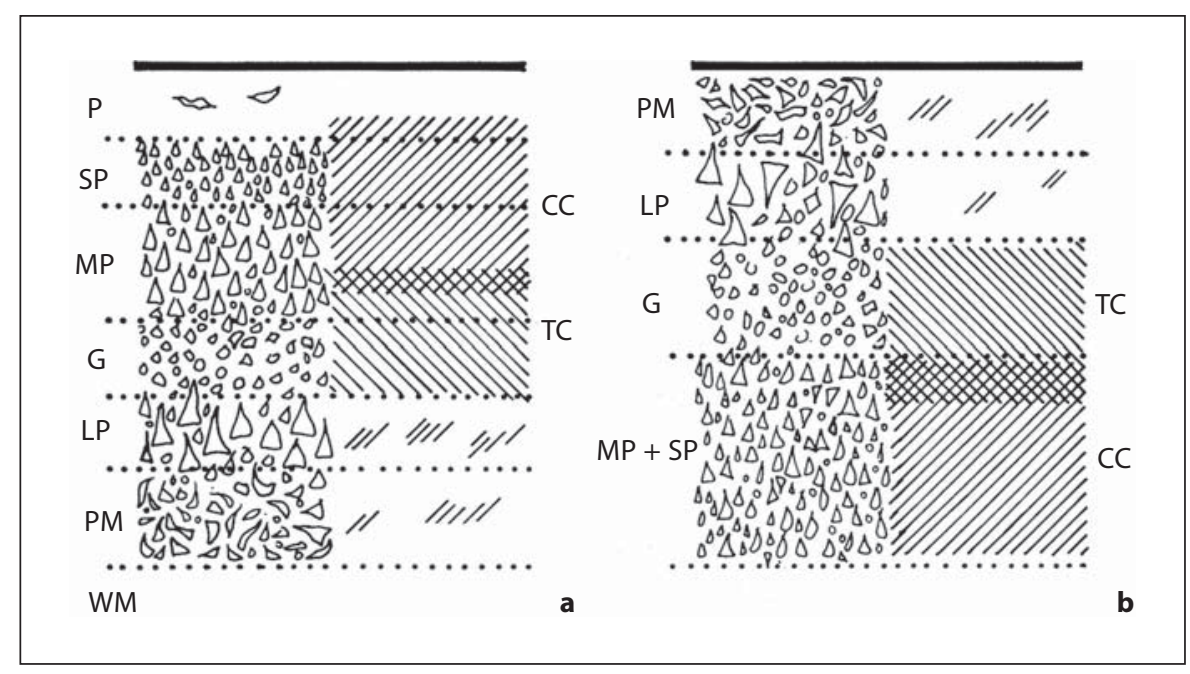

Fig. 5. Schematic representation of the distribution of basic neuronal classes and their major afferent systems in normal $+/-$ (a) and reeler $\mathrm{rl} / \mathrm{rl}(\mathbf{b})$ neocortex. The left half of $\mathbf{a}$ displays the normal positions of the plexiform layer (P), layer of small pyramids (SP), layer of medium pyramids (MP), layer of granule (stellate) cells (G), layer of large pyramids (LP), layer of polymorphous cells (PM) and the subcortical white matter (WM). The left half of b shows the relative distributions of the homologous classes of neurons in the corresponding cortical areas in the reeler mouse.
Note the absence of the plexiform layer and misplacement and/or inversion of position of some cell classes. The right halves of $\mathbf{a}$ and b indicate the territories occupied by callosal (CC) and by thalamocortical terminals (TC) in the normal or reeler mouse, respectively. The distribution of thalamocortical and callosal terminal afferent systems to the neocortex varies in normal and mutant cortex, depending on the position of the target cells [Caviness and Rakic, 1978].
[O'Leary and Nakagawa, 2002; Grove and Fukuchi-Shimogori, 2003]. Among the observations that have favored specification occurring prior to the postmitotic state and migration has been that cortical neurons greatly out of position in the reeler mutant mouse not only express principal class characteristic features, but also observe strictly the rules of specificity in the formation of their principal connections including thalamocortical and callosal connections [Devor et al., 1975; Caviness and Yorke, 1976; Caviness and Frost, 1983] (fig. 5). There is the additional evidence that neurons of callosal association may elaborate their axons correctly even before they complete their migrations [Schwartz et al., 1991] and that the topology of thalamocortical connectivity is established by embryonic day 16 in the mouse [Caviness, 1988], a stage of cortical development where only the infragranular neurons have completed their migration and are in place. Decisive evidence comes, however, from the Gbx-2 mutant, in which cortical laminar assembly and regionalization appear to be largely appropriate despite the fact that the mutant has no thalamocortical projection [Miyashita-Lin et al., 1999]. Nevertheless, it is also evident that there are profound secondary features of neurons, including their patterns of dendritic arborization [Maria- ni et al., 1977; Pinto and Caviness, 1979], the formation of barrel configuration in the S1 murine field [Woolsey and van der Loos, 1970; Woolsey and Wann, 1976] and ocular dominance in larger mammals with binocular vision [Hubel et al., 1977] that are predominantly determined by interaction with postmigratory neurons and their afferent inputs.

The proliferative process itself proceeds with tight precision along a gradient that extends along the TNG from the rostrolateral to caudomedial borders of the hemisphere (fig. 6). We have shown in the mouse that aligned with the TNG there is an orderly advance in the duration of the cell cycle during which only the $G_{1}$ phase (TG1) is lengthened [Takahashi et al., 1995a; Miyama et al., 1997]. Coordinated with the lengthening of TG1, there is an increase in the fraction of postmitotic cells that exits each cell cycle $(\mathrm{Q})$ and a commensurate decline in the fraction that will return to the cycle $(\mathrm{P} ; \mathrm{Q}+\mathrm{P}=$ 1.0) [Takahashi et al., 1996]. The parameters $Q$ and $T G 1$ govern more general regulatory aspects of the proliferative process. Thus, the cycle-to-cycle increase in $\mathrm{Q}$ as $\mathrm{Q}$ ascends its obligatory path from 0.0 (before the first cell becomes postmitotic) to 1.0 (the cycle at which the proliferative population disappears and the last postmitotic 


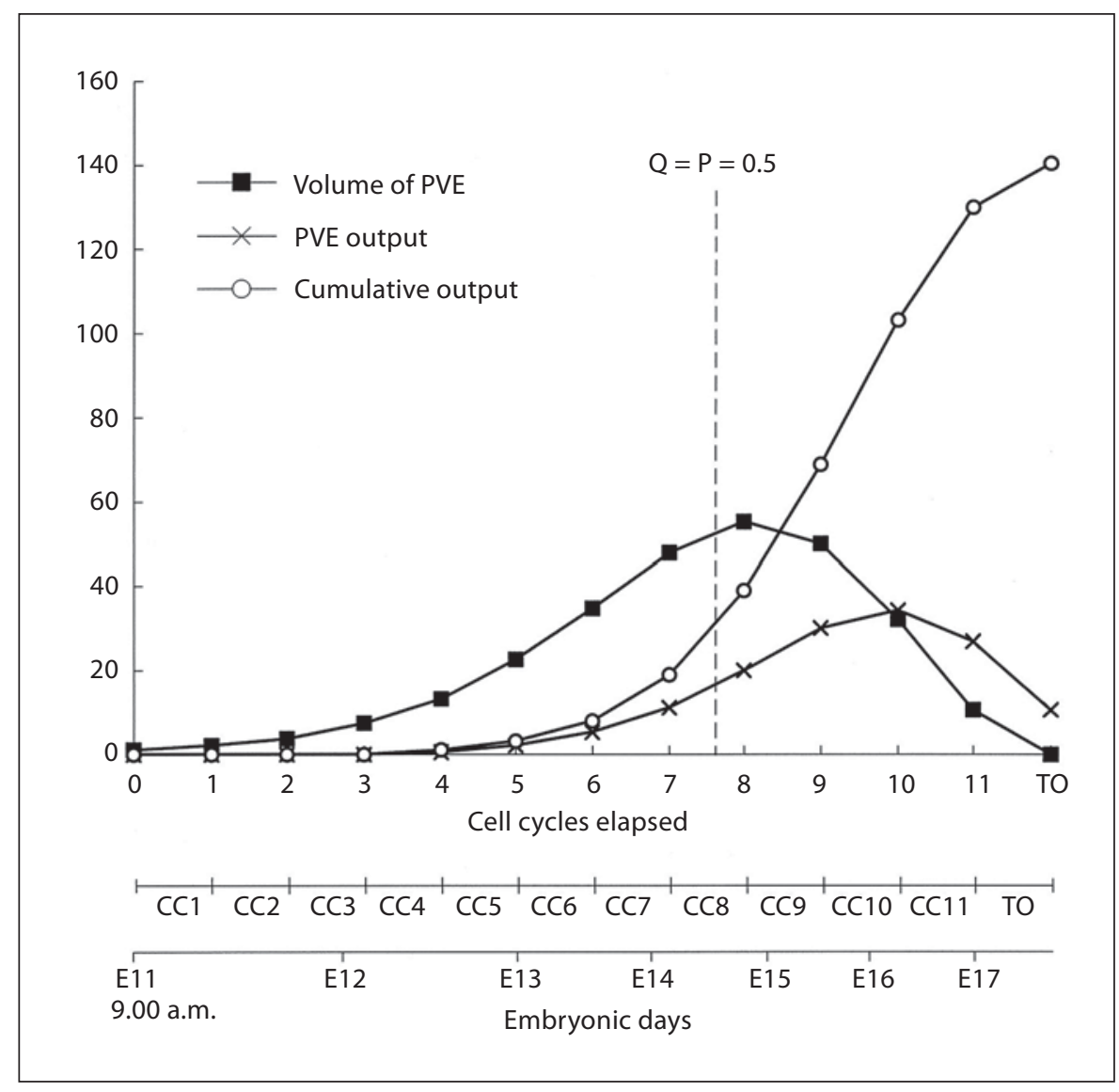

Fig. 6. Expansion and involution of a founder PVE population and cell output in the course of the neuronogenetic interval. The volume of the PVE, the cell output from a single cell cycle (PVE output) and the cumulative cell output are plotted with respect to both the elapsed cell cycles, CC1-CC11, and embryonic days (E) on the abscissa. At the beginning of the neuronogenetic interval, where 0 cell cycles have elapsed (i.e. the beginning of CC1) at 9.00 a.m. on E11, the PVE volume is set at the arbitrary unit value of 1.0 , and cell output at this point is by definition 0 . The vertical dashed line divides the neuronogenetic interval with respect to where $Q$ and $P$ reach the critical turning point of 0.5 . To the left of the vertical dashed line, $\mathrm{Q}<0.5$ and the PVE is expanding; to the right of the vertical dashed line, Q $>0.5$ and the PVE is involuting. The PVE size reaches its maximum value at this point, and

cells arise) determines the total number of cycles that will constitute the overall proliferative process [Caviness et al., 2000a; Nowakowski et al., 2002]. The rate at which a given cell cycle domain propagates along the TNG in turn will be proportional to $2 \times$ the duration of the cell cycle [Caviness et al., 2000a]. Finally as evidence of the close coordination between proliferative mechanisms and those involved in specification, it turns out that across the PVE there is a close correlation between cell cell output per cycle is maximum beyond this point. The $\mathrm{P}$ fraction cells of CC11 will divide to produce 2 daughter cells, all of which $(\mathrm{Q}=1.0)$ will exit the cell cycle as the terminal output (TO). The contribution of $\mathrm{Q}$ from the first half of the 11 cell cycles (CC1-CC6) is only approximately 6\%, whereas that of the last 2 cycles (CC10-CC11) and the terminal output is about $50 \%$ of the total neuronal population of the cortex at the end of the neuronogenetic interval. Our previous estimate of the cumulative output throughout the full neuronogenetic interval [Caviness et al., 1995] was approximately twice that represented here. This is because the unit founder population was considered to be the population of the cell cycle preceding $\mathrm{CC} 1$ for the previous estimate but was considered to be the population at the beginning of $\mathrm{G}_{1}$ of $\mathrm{CC} 1$ in this plot [Takahashi et al., 1996]. 


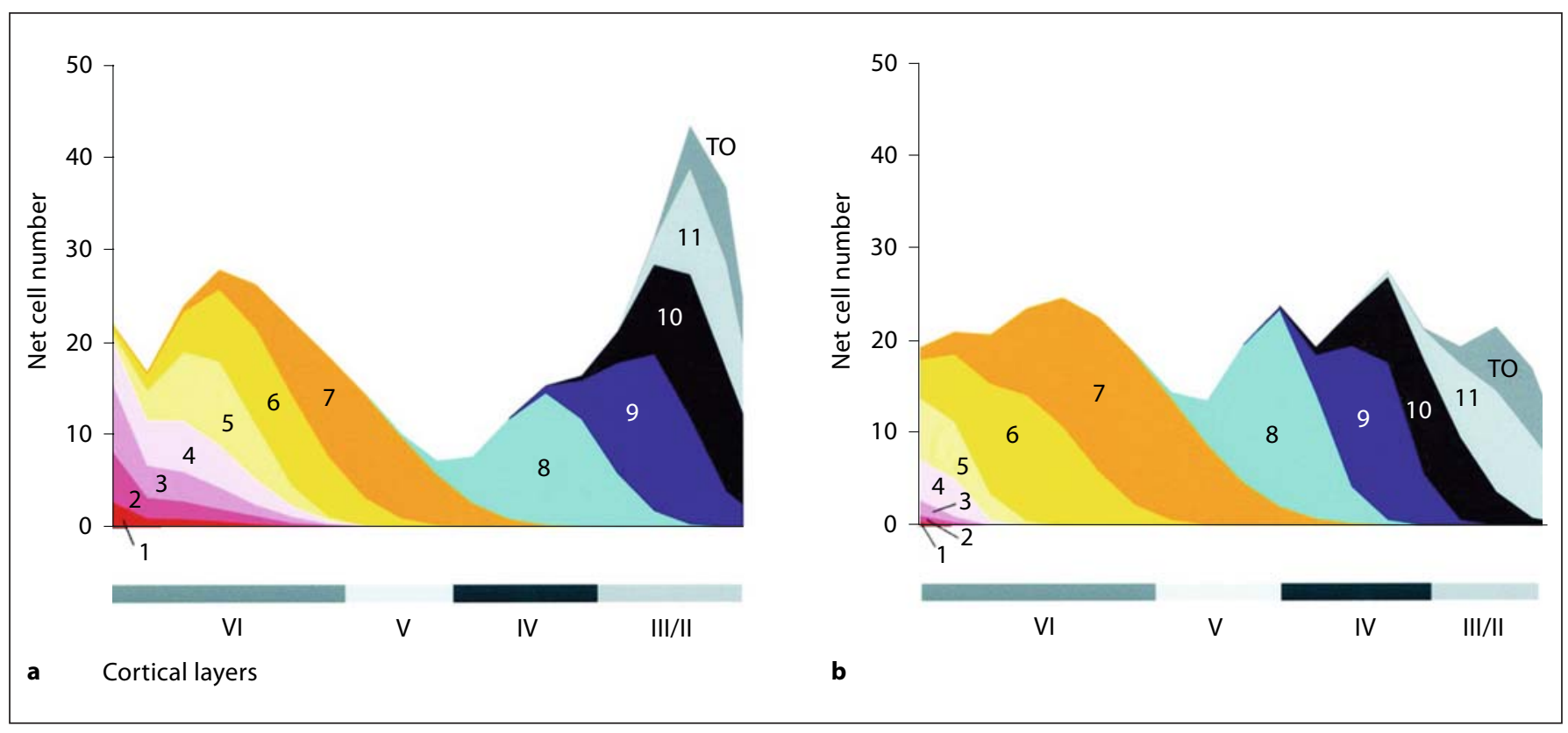

Fig. 7. A schematic diagram of the contribution, patterns of distribution and intermixing of neurons by cycle of origin. This plot is a summary of the individual distributions plotted in figure 4 and shows the contribution and distribution pattern of net output from each cycle to each cortical layer. The output of each cycle is color coded and numbered. TO refers to the terminal output after cycle 11 at the end of the neuronogenetic interval. Cell number per counting sector (ordinate; also see Materials and Methods) is a net number, that is a number that is obtained at postnatal day 22 after histogenetic cell death has been completed. Net neuronal output is lowest to the midcortex, corresponding to layer $\mathrm{V}$, where the contribution arises principally with cycles 7 and 8 in both fields. It is evident that all layers, and particularly the deepest levels of layer VI, represent the contributions of many cycles [Takahashi et al., 1999]. a Field 1. b Field 40. suggesting that the class specification sequence is coordinated with Q [Tarui et al., 2001] (fig. 8, 9). This suggests that $\mathrm{Q}$ for each cycle is not only an index of the probability that any postmitotic cell will exit the cycle, but also an index of the probability that this cell will be a neuron of a specific laminar class.

With these considerations in mind, the relationship of the proliferative process to the regulated delivery of the successive laminar neuron classes in appropriate numbers becomes apparent. The ascent of Q from 0.0 to 1.0 is nonlinear but monotonic, rising slowly during the first several cycles, then more rapidly to cross the steady-state value of $\mathrm{Q}$ of 0.5 and continue beyond to exhaustion of the proliferative process with the final cycle at $\mathrm{Q}$ of 1.0 [Takahashi et al., 1996] (fig. 6). At $Q=0.5$ the number of cells exiting the cycle is equal to that remaining to sustain the proliferative pool. Prior to this the proliferative pool is expanding in both its radial and tangential dimensions while afterwards it is contracting but only in its radial dimension. In the mouse, the expansion of the proliferative pool in the interval before Q passes 0.5 is approxi- mately 50 -fold while the overall multiplicative factor for a given lineage is about 150 -fold. The corresponding multiplier values are orders of magnitude greater in larger mammals, in particular in primates where some of this type of data has been collected [Kornack and Rakic, 1998; Nowakowski et al., 2002]. Two points pertinent to earlier discussion follow [Takahashi et al., 1997; Kornack and Rakic, 1998]. The first is that it would be at $\mathrm{Q}=0.5$ where the PVE has reached its maximum tangential extent, that one would expect regional specification with the PVE (the protomap) to be consummated [Takahashi et al., 1996; Caviness et al., 2000a]. This is consistent with the observation that when cells arising when $\mathrm{Q}$ is about 0.5 complete their migrations they are essentially immediately able to enter into a thalamocortical network that is topologically the same as that of the adult projection [Caviness, 1988]. The second is that for the large number of genetic defects that result in microcephaly characterized by impoverishment of the outer cortical layers, the mechanisms must be mediated via an orderly advance in the rate of progression of $\mathrm{Q}$ with cycle [Caviness et al., 


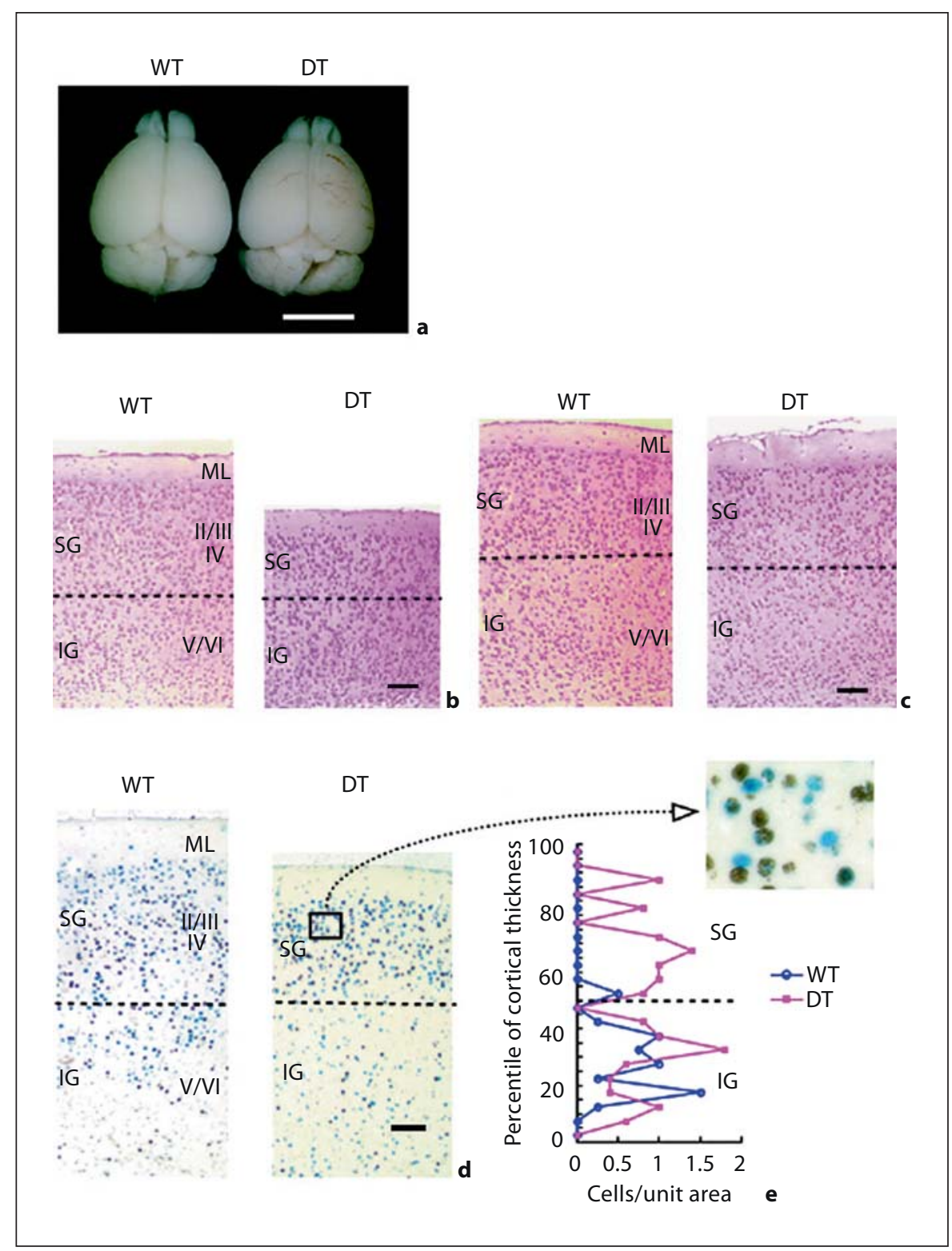

Fig. 8. Effect of $\mathrm{p} 27^{\mathrm{Kip} 1}$ overexpression on the laminar fate of neocortical neurons. Effects of $\mathrm{p} 27^{\mathrm{Kip} 1}$ overexpression during the embryonic period on the gross appearance of the brain, cytoarchitecture of the neocortex and laminar fates of cells generated on embryonic day 14 examined at postnatal day 21. The brains of wild-type (WT) and double transgenic (DT) mice appear similar in size and shape at postnatal day 21 (a). b, c Micrographs of 4$\mu \mathrm{m}$-thick coronal sections through field 1 (b) and field 40 (c) of WT and DT mice stained with basic fuchsin to reveal cortical lamination. The cytoarchitecture of fields 1 and 40 is preserved in the DT mice. However, the thickness of the cortical gray matter is reduced dramatically in the DT mouse in field 1 compared to the WT littermates (b). The thickness of the gray matter in field 40 is similar in the DT and WT mice (c). The reduction in the thickness of field 1 is caused mainly by a marked reduction in the thickness of supragranular (SG) layers (layers II/III and IV, b). The thickness of infragranular (IG) layers (layers V and VI) is similar in the DT and WT littermates in fields 1 and 40 (b, c). d Micrographs of $4-\mu$ m-thick coronal sections through field 1 of postnatal day $21 \mathrm{WT}$ and DT littermates processed for iododeoxyuridine and bromodeoxyuridine immunohistochemistry. At higher magnification (box insert), iododeoxyuridine-only (blue labeled) cells are readily distinguished from cells labeled with bromodeoxyuridine (brown containing). e Quantitative analysis of the distribution of the iododeoxyuridine-only labeled cells (i.e. cells that exited the cell cycle on embryonic day 14) in field 1 at postnatal day 21 revealed that the majority of the cells was distributed in the infragranular (IG) layers in the WT cortex (blue line) and in the supragranular (SG) layers in the DT cortex (red line) at postnatal day 21. Thus, layer destination of cells generated on embryonic day 14 was shifted toward the supragranular layers in the DT mice. $\mathrm{ML}=$ Molecular layer (layer I). a Scale bar = $5 \mathrm{~mm}$. b-d Scale bar $=100 \mu \mathrm{m}$ [Tarui et al., 2005]. 


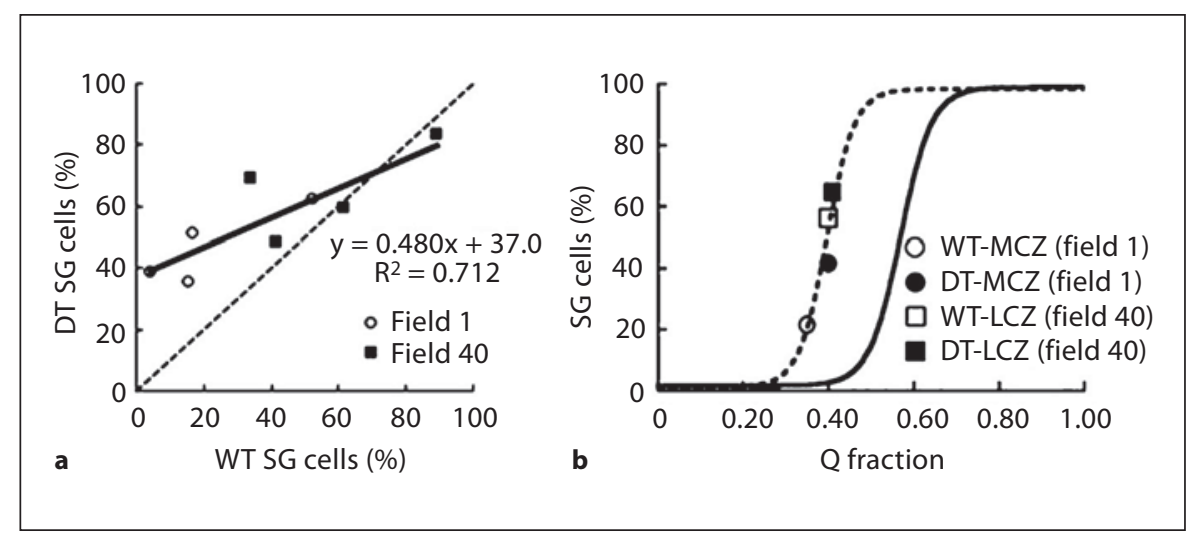

Fig. 9. The regulatory linkage among $\mathrm{p} 27^{\mathrm{Kip} 1}$ overexpression, cell output and cell fate. a Regression analysis of the percentage of Q cells directed to granular and supragranular (SG) layers in fields 1 and 40 in wild-type (WT) and double transgenic (DT) littermate pairs. The dashed line (with 45-degree slope) denotes the 'no effect' line, representing a hypothetical function, in which DT and WT littermates have identical values (i.e. no effect of p $27^{\mathrm{Kip} 1}$ overexpression). The slope of the regression line obtained with the actual data is significantly ( $t$ test, $p=0.01$ ) lower than that of the 'no effect' line, indicating that the percentage of cells directed to the SG layers was greater in DT mice compared to the WT littermates. Moreover, the field 1 values diverge from the 'no effect' line to a greater extent than the field 40 values, which tend to approximate the line closely. $\mathbf{b}$ The percentage of cells that exited the cell cycle on embryonic day 14 and that occupied SG layers at postnatal day 21 in the WT and DT mice is plotted as function of the probability of cell cycle exit (Q). The solid line represents data from the CD1 mouse strain obtained in our earlier work [Taka- hashi et al., 1996, 1999]. The data from the current study are plotted as dashed line. Nonlinear regression curves are obtained for both the sets of data. Q values were measured in the ventricular zone of the cerebral wall in the medial and lateral cortical zones (MCZ and LCZ, respectively) on embryonic day 14 . The MCZ and LCZ are precursors of fields 1 and 40, respectively. The MCZ and $\mathrm{LCZ}$ are separated from each other along the transverse neurogenetic gradient so that the LCZ progenitors are 'in advance' of the MCZ progenitors with regard to cell cycle kinetics. The correlation between Q and percentage of SG cells observed in the WT mice also applies to the DT mice despite the p27 ${ }^{\mathrm{Kip} 1}$ overexpression-induced increase in Q. Thus, when Q increases, percent SG increases proportionately, both in the MCZ and the LCZ and both in the WT and DT mice. This indicates that the probability of origin of a given laminar neuron class is a function of the probability of cell cycle exit, regardless of position along the TNG [Tarui et al., 2005].
2003]. This would lead to a late impoverishment of the proliferative pool of the PVE from which these cells arise.

\section{Postproliferative Events as Determinants of Architectonic Pattern}

The reeler mutant mouse has contributed both insight and consternation to this discourse. The mutant was initially recognized and sustained because of its reeling ataxia of gait [Caviness and Rakic, 1978]. Histological examination of the brain identified a universal and dramatic pattern abnormality involving all cortical structures with the exception of the olfactory bulb. Early studies concluded that cell pattern was random, that is without any systematic principle of pattern, and studies based upon dissociation reaggregation experiments in vitro led to the hypothesis that the reeler gene was a master corti- cal gene that was an indispensable universal determinant of cortical pattern [DeLong and Sidman, 1970; Sidman, 1970]. Reexamination of this material subsequently led to the realization that the cells were not distributed randomly; in fact there was an underlying consistent anomaly in cell position in all affected cortical structures. In the neocortex, architectonic studies based on general cell stains suggested, and pulse chase $\mathrm{S}$ phase autoradiography confirmed, that there was a systematic inversion of the radial order of neurons with respect to time of origin [Caviness and Sidman, 1972, 1973; Devor et al., 1975; Caviness, 1976, 1982]. That is, rather than being insideout as in the normal, it was outside-in. There appeared to be no problems with the proliferative mechanisms and their sequences, and the appropriate classes arose in the appropriate order. Moreover, the cortical neurons retained their principal class characteristic features of size and pattern of afferent and efferent connections despite malposition (fig. 5). Moreover, they appeared to migrate 
more or less appropriately until they reached the cortical domain. At that point, from the vantage of electron microscopy, they appeared to freeze in place and in the order that they entered the cortical plane [Pinto-Lord et al., 1982]. In short, the right cells were born at the right time but during their migration they failed to reach the right place.

Subsequent work has cloned the gene, characterized the protein and provided critical insights with respect to its cell classes of origin and about the signaling cascade in which the reeler gene participates [Goffinet, 1995; D'Arcangelo et al., 1997]. Moreover, a variety of 'lookalikes' and near-look-alikes have turned up, some with related and some with unrelated molecular affinities [Gilmore et al., 1998; Ohshima et al., 1999; Ross and Walsh, 2001; Forster et al., 2006]. The mechanisms through which the protein encoded by the normal reeler gene acts to facilitate migration within the cortical plane remains illusive, but considerable progress has been made in understanding the reelin signaling cascade [Forster et al., 2006]. The modern era of work on reeler proceeded concurrently with the signal discovery of Rakic [1971] that the course of migration was guided in its ascent by adherence to the transcerebral radial glial fiber. Certainly this mechanism is among the most indispensable to pattern formation, and recent work, much based upon developmental malformations in man, has begun to identify its vulnerabilities [Mochida and Walsh, 2004]. For example, it is clear from such work that molecular mechanisms related to cytoskeletal elements that are components of migratory mechanisms, are indispensable. The human malformation Lis1, for example, in which there is massive arrest of neuronal migration at a cerebral level superficial to the sagittal strata and within the corona radiata [Stewart et al., 1975], arises from a mutation in the lisl gene [Pilz et al., 1998]. In this mutation and the closely related 'double cortex' malformation [Corbo et al., 2002] designated originally by Bielschowsky as pachygyria [Stewart et al., 1975], it is the microtubular system that is disordered. In periventricular nodular heterotopia, the heterotopic neurons are clustered in nodules just above the proliferative epithelium. The mutated gene in this instance is filamen, a component in the microfilament system [Fox and Walsh, 1999; Sheen et al., 2002].

The final events involved in fine tuning cortical patterning occur within the cortex itself and involve postmigratory cells. There is a complex and extended sequence of developmental processes continuing through all that occurs with the formation of connections and growth. We mention here two critical early events that occur soon after neurons have completed their ascent along the radial glial fiber. We cite first the process of winnowing by histogenetic cell death. This is a process, massive in scale, for which the regulatory mechanisms are little understood. It was appreciated more than 2 decades ago by Finlay and associates that this was a process of great magnitude [Finlay and Slattery, 1983; Janowsky and Finlay, 1983; Finlay et al., 1986; Finlay and Pallas, 1989]. They postulated that in fact the differences in neuron number from area to area and layer to layer within an area were due principally to differential magnitudes of histogenetic cell death rather than differential neuron complement after proliferation and migration. This hypothesis is consistent with the observation based upon quantitative studies. These establish first of all that the same number of neurons appear to be formed in the course of proliferation in multiple regions of the PVE giving rise to the neuronal population in multiple different architectonic fields [Takahashi et al., 1996; Caviness et al., 2000a]. Secondly, in different and widely separate cortical areas and in the separate layers within these areas, the amount of cell death is greatly variable and consistent with a reasonable approximation of the final complement of those layers and fields [Verney et al., 2000]. In the mouse, the process peaks at postnatal day 4 , that is, within $48-72 \mathrm{~h}$ of the completion of migration, and is completed before the end of the second postnatal week. It appears to proceed concurrently in all fields rather than observing the earlier cytogenetic sequence in the PVE. In this way it is similar to the schedule of synaptogenesis [Bourgeois et al., 1994; Granger et al. 1995; Bourgeois and Rakic, 1996]. This is consistent with the hypothesis that it is governed principally by a process of system matching that is an interaction between cell and afferent systems [O'Leary and Cowan, 1982, 1984; Carlson et al., 1986].

Once the cells have reached their proper position in the neocortex and established their final number by cell death and their appropriate connections with their afferent and efferent targets, additional steps occur to shape the final function of the neocortex. One of these, the production of myelin, has been known for many years [Flechsig, 1920] to occur in a specific order that corresponds apparently to the functional needs of the developing infant. Other processes, notably the development of the cortical columns, require functional interactions that include sensory input [Rakic, 1976; Wiesel, 1982; Kanold and Shatz, 2006].

The sequence of histogenetic events reviewed in brief in these paragraphs is robust, orderly and greatly precise in execution under conditions of normal genetic back- 
ground and favorable environmental circumstances. However, genetic flaws or unfavorable environmental conditions regularly precede a greatly diverse range of disorders reflecting disruption of a series of entrained histogenetic sequences. The gravest of these may be reflected in topological disruptions with profound limitation of growth while others may be detected only in domains of behavioral adaptation [Caviness et al., 2000b; Takahashi et al., 2003]. The direction of thought over the past century has moved strongly from a grounding in formal origin of the nervous system and its cell biological basis towards an enlarging grasp of molecular biological regulation. It is in this domain of exploration that we place our strongest expectations for an understanding that will lessen the probability and burden of histogenetic failures.

\section{Acknowledgements}

This work was supported by US Public Health Service grants NS12005 to V.S.C., NS43246 and DA020796 to P.G.B., NS49445 and EY15647 to R.S.N., and a grant from the NJ Commission on Spinal Cord Research to R.S.N.

\section{References}

Angevine JB, Sidman RL (1961): Autoradiographic study of cell migration during histogenesis of the cerebral cortex in the mouse. Nature 192:766-768.

Bayer SA, Altman J (1991): Neocortical Development. New York, Raven Press.

Boulder Committee (1970): Embryonic vertebrate nervous system: revised terminology. Anat Rec 166:257-262.

- Bourgeois JP, Goldman-Rakic PS, Rakic P (1994): Synaptogenesis in the prefrontal cortex of rhesus monkeys. Cereb Cortex 4:78-96.

Bourgeois JP, Rakic P (1996): Synaptogenesis in the occipital cortex of macaque monkey devoid of retinal input from early embryonic stages. Eur J Neurosci 8:942-950.

Brodmann K (1909): Vergleichende Lokalisationslehre der Grosshirnrinde. Leipzig, Barth

-Carlson M, Hubel DH, Wiesel TN (1986): Effects of monocular exposure to oriented lines on monkey striate cortex. Brain Res 390:71-81.

- Caviness V Jr (1976): Patterns of cell and fiber distribution in the neocortex of the reeler mutant mouse. J Comp Neurol 170:435447.

Caviness V Jr (1982): Neocortical histogenesis in normal and reeler mice: a developmental study based upon $\left[{ }^{3} \mathrm{H}\right]$ thymidine autoradiography. Brain Res 256:293-302.

Caviness V Jr (1988): Architecture and development of the thalamocortical projection in the mouse; in Bentivoglio M, Spreafico R (eds): Cellular Thalamic Mechanisms. Amsterdam, Elsevier Science Publishers, pp 489-499.

-Caviness V Jr, Takahashi T, Nowakowski RS (1995): Numbers, time and neocortical neurogenesis: a general developmental and evolutionary model. Trends Neurosci 18:379383.

-Caviness V Jr, Frost DO (1983): Thalamocortical projections in the reeler mutant mouse. $\mathrm{J}$ Comp Neurol 219:182-202.
Caviness VS Jr, Goto T, Tarui T, Takahashi T, Bhide PG, Nowakowski RS (2003): Cell output, cell cycle duration and neuronal specification: a model of integrated mechanisms of the neocortical proliferative process. Cereb Cortex 13:592-598.

Caviness VS Jr, Rakic P (1978): Mechanisms of cortical development: a view from mutations in mice. Annu Rev Neurosci 1:297-326.

Caviness V Jr, Sidman RL (1972): Olfactory structures of the forebrain in the reeler mutant mouse. J Comp Neurol 145:85-104.

Caviness V Jr, Sidman RL (1973): Time of origin or corresponding cell classes in the cerebral cortex of normal and reeler mutant mice: an autoradiographic analysis. J Comp Neurol 148:141-151.

Caviness V Jr, Takahashi T, Nowakowski RS (2000a): Neuronogenesis and the early events of neocortical histogenesis; in Goffinet A, Rakic P (eds): Development of the Neocortex. Berlin, Springer, pp 107-143.

Caviness VS Jr, Takahashi T, Nowakowski RS (2000b): Neocortical malformation as consequence of nonadaptive regulation of neuronogenetic sequence. Ment Retard Dev Disabil Res Rev 6:22-33.

Caviness V Jr, Yorke C Jr (1976): Interhemispheric neocortical connections of the corpus callosum in the reeler mutant mouse: a study based on anterograde and retrograde methods. J Comp Neurol 170:449-459.

Corbo JC, Deuel TA, Long JM, LaPorte P, Tsai E, Wynshaw-Boris A, Walsh CA (2002): Doublecortin is required in mice for lamination of the hippocampus but not the neocortex. J Neurosci 22:7548-7557.

Cunningham D (1895): The brain of the microcephalic idiot. London, The Royal Dublin Society, Williams \& Norgate.

-D’Arcangelo G, Nakajima K, Miyata T, Ogawa M, Mikoshiba K, Curran T (1997): Reelin is a secreted glycoprotein recognized by the CR-50 monoclonal antibody. J Neurosci 17 : 23-31.
DeLong GR, Sidman R (1970): Alignment defect of reaggregating cells in cultures of developing brains of Reeler mutant mice. Dev Biol 22:584-600.

Devor M, Caviness V Jr, Derer P (1975): A normally laminated afferent projection to an abnormally laminated cortex: some olfactory connections in the reeler mouse. J Comp Neurol 164:471-482.

Finlay BL, Pallas SL (1989): Control of cell number in the developing mammalian visual system. Prog Neurobiol 32:207-234.

- Finlay BL, Sengelaub DR, Berian CA (1986): Control of cell number in the developing visual system. I. Effects of monocular enucleation. Dev Brain Res 28:1-10.

Finlay BL, Slattery M (1983): Local differences in the amount of early cell death in neocortex predict adult local specializations. Science 219:1349-1351.

Flechsig P (1920): Anatomie des menschlichen Gehirns und Rückenmarks auf myelogenetischer Grundlage. Leipzig, Thieme.

Forster E, Jossin Y, Zhao S, Chai X, Frotscher M, Goffinet AM (2006): Recent progress in understanding the role of Reelin in radial neuronal migration, with specific emphasis on the dentate gyrus. Eur J Neurosci 23:901909.

Fox JW, Walsh CA (1999): Periventricular heterotopia and the genetics of neuronal migration in the cerebral cortex. Am J Hum Genet 65:19-24.

- Gilmore EC, Ohshima T, Goffinet AM, Kulkarni AB, Herrup K (1998): Cyclin-dependent kinase 5-deficient mice demonstrate novel developmental arrest in cerebral cortex. J Neurosci 18:6370-6377.

-Goffinet AM (1995): Developmental neurobiology: a real gene for reeler. Nature 374:675676 . 
- Granger B, Tekaia F, Le Sourd AM, Rakic P, Bourgeois JP (1995): Tempo of neurogenesis and synaptogenesis in the primate cingulate mesocortex: comparison with the neocortex. J Comp Neurol 360:363-376.

-Grove EA, Fukuchi-Shimogori T (2003): Generating the cerebral cortical area map. Annu Rev Neurosci 26:355-380.

Hammarberg C (1895): Studien über Klinik und Pathologie der Idiotie nebst Untersuchungen über die normale Anatomie der Hirnrinde. Upsala, Druck der Akademischen Buchdruckerei.

His W (1889): Die Neuroblasten und deren Entstehung im embryonalen Mark. Abh Math Phys Cl Kgl Saechs Ges Wiss 15:313-372.

His W (1904): Die Entwicklung des menschlichen Gehirns während der ersten Monate. Leipzig, Hirzel.

-Hubel D, Wiesel TN, LeVay S (1977): Plasticity of ocular dominance columns in monkey striate cortex. Phil Trans R Soc Lond B 278:377409.

-Janowsky JS, Finlay BL (1983): Cell degeneration in early development of the forebrain and cerebellum. Anat Embryol 167:439-447.

Kanold PO, Shatz CJ (2006): Subplate neurons regulate maturation of cortical inhibition and outcome of ocular dominance plasticity. Neuron 51:627-638.

Kornack DR, Rakic P (1998): Changes in cell-cycle kinetics during the development and evolution of primate neocortex. Proc Natl Acad Sci USA 95:1242-1246.

Kriegstein AR (2005): Constructing circuits: neurogenesis and migration in the developing neocortex. Epilepsia 46(suppl 7):15-21.

-Mariani J, Crepel F, Mikoshiba K, Changeux JP, Sotelo C (1977): Anatomical, physiological and biochemical studies of the cerebellum from Reeler mutant mouse. Philos Trans R Soc Lond B Biol Sci 281:1-28.

-Miyama S, Takahashi T, Nowakowski RS, Caviness VS Jr (1997): A gradient in the duration of the $G_{1}$ phase in the murine neocortical proliferative epithelium. Cereb Cortex 7: 678-689.

-Miyashita-Lin E, Hevner R, Wassarman K, Martinez S, Rubenstein J (1999): Early neocortical regionalization in the absence of thalamic innervation. Science 285:906-909.

Mochida GH, Walsh CA (2004): Genetic basis of developmental malformations of the cerebral cortex. Arch Neurol 61:637-640.

-Monuki ES, Porter FD, Walsh CA (2001): Patterning of the dorsal telencephalon and cerebral cortex by a roof plate-Lhx2 pathway. Neuron 32:591-604.

Nowakowski R, Caviness V, Takahashi T, Hayes N (2002): Population dynamics during cell proliferation and neuronogenesis in the developing murine neocortex; in Hohmann $\mathrm{C}$ (ed): Cortical Development: From Specification to Differentiation. New York, Springer, pp 1-22.
Ohshima T, Gilmore EC, Longenecker G, Jacobowitz DM, Brady RO, Herrup K, Kulkarni AB (1999): Migration defects of cdk5(-/-) neurons in the developing cerebellum is cell autonomous. J Neurosci 19:6017-6026.

O'Leary DD, Cowan WM (1982): Further studies on the development of the isthmo-optic nucleus with special reference to the occurrence and fate of ectopic and ipsilaterally projecting neurons. J Comp Neurol 212:399416.

O'Leary DD, Cowan WM (1984): Survival of isthmo-optic neurons after early removal of one eye. Brain Res 314:293-310.

O'Leary DD, Nakagawa Y (2002): Patterning centers, regulatory genes and extrinsic mechanisms controlling arealization of the neocortex. Curr Opin Neurobiol 12:14-25.

-Pilz DT, Matsumoto N, Minnerath S, Mills P, Gleeson JG, Allen KM, Walsh CA, Barkovich AJ, Dobyns WB, Ledbetter DH, Ross ME (1998): LIS1 and XLIS (DCX) mutations cause most classical lissencephaly, but different patterns of malformation. Hum Mol Genet 7:2029-2037.

Pinto LM, Caviness V Jr (1979): Determinants of cell shape and orientation: a comparative Golgi analysis of cell-axon interrelationships in the developing neocortex of normal and reeler mice. J Comp Neurol 187:49-69.

Pinto-Lord MC, Evrard P, Caviness V Jr (1982): Obstructed neuronal migration along radial glial fibers in the neocortex of the reeler mouse: a Golgi-EM analysis. Brain Res 256: 379-393.

Rakic P (1971): Neuron-glia relationship during granule cell migration in developing cerebellar cortex: a Golgi and electronmicroscopic study in Macacus rhesus. J Comp Neurol 141:283-312.

Rakic P (1976): Prenatal genesis of connections subserving ocular dominance in the rhesus monkey. Nature 261:467-471.

Rakic P (1988): Specification of cerebral cortical areas. Science 241:170-176.

Ross ME, Walsh CA (2001): Human brain malformations and their lessons for neuronal migration. Annu Rev Neurosci 24:10411070.

Roy K, Kuznicki K, Wu Q, Sun Z, Bock D, Schutz G, Vranich N, Monaghan AP (2004): The Tlx gene regulates the timing of neurogenesis in the cortex. J Neurosci 24:8333-8345.

-Sauer FC (1935): Mitosis in the neural tube. J Comp Neurol 62:377-405.

Sauer FC (1936): The interkinetic migration of embryonic epithelial nuclei. J Morphol 60: $1-11$.

Schwartz ML, Rakic P, Goldman-Rakic PS (1991): Early phenotype expression of cortical neurons: evidence that a subclass of migrating neurons have callosal axons. Proc Nat Acad Sci USA 88:1354-1358.
Sheen VL, Feng Y, Graham D, Takafuta T, Shapiro SS, Walsh CA (2002): Filamin A and filamin B are co-expressed within neurons during periods of neuronal migration and can physically interact. Hum Mol Genet 11: 2845-2854.

Sidman R (1970): Cell proliferation, migration and interaction in the developing mammalian central nervous system; in Schmidt F (ed): The Neurosciences Second Study Program. New York, Rockefeller University Press.

Sidman RL, Miale IL, Feder N (1959): Cell proliferation and migration in the primitive ependymal zone: an autoradiographic study of histogenesis in the nervous system. Exp Neurol 1:322-333.

Sidman RL, Rakic P (1982): Development of the human central nervous system; in Haymaker W, Adams RD (eds): Histology and Histopathology of the Nervous System. Springfield, Thomas, pp 3-145.

Smart IH, Smart M (1982): Growth patterns in the lateral wall of the mouse telencephalon. I. Autoradiographic studies of the histogenesis of the isocortex and adjacent areas. J Anat 134:273-298.

Stewart RM, Richman DP, Caviness V Jr (1975): Lissencephaly and pachygyria: an architectonic and topographical analysis. Acta Neuropathol 31:1-12.

-Takahashi T, Goto T, Miyama S, Nowakowski RS, Caviness VS Jr (1999): Sequence of neuron origin and neocortical laminar fate: relation to cell cycle of origin in the developing murine cerebral wall. J Neurosci 19:1035710371

Takahashi T, Kinsman S, Makris N, Grant E, Haselgrove C, McInerney S, Kennedy DN, Fredrickson K, Mori S, Caviness VS (2003): Semilobar holoprosencephaly with midline 'seam': a topologic and morphogenetic model based upon MRI analysis. Cereb Cortex 13:1299-1312.

Takahashi T, Nowakowski RS, Caviness V Jr (1995a): The cell cycle of the pseudostratified ventricular epithelium of the embryonic murine cerebral wall. J Neurosci 15:6046-6057.

-Takahashi T, Nowakowski RS, Caviness VS Jr (1995b): The cell cycle of the pseudostratified ventricular epithelium of the embryonic murine cerebral wall. J Neurosci 15:6046-6057.

-Takahashi T, Nowakowski RS, Caviness VS Jr (1996): The leaving or Q fraction of the murine cerebral proliferative epithelium: a general model of neocortical neuronogenesis. J Neurosci 16:6183-6196.

- Takahashi T, Nowakowski R, Caviness V Jr (1997): The mathematics of neocortical neuronogenesis. Dev Neurosci 19:17-22.

Tarui T, Takahashi T, Bhide P, Caviness V (2001): Effects of $\mathrm{p} 27^{\mathrm{kip} 1}$ overexpression on neocortical neurogenesis are developmentally regulated. Soc Neurosci Abstr 27:896. 
- Tarui T, Takahashi T, Nowakowski RS, Hayes NL, Bhide PG, Caviness VS (2005): Overexpression of p27 Kip 1, probability of cell cycle exit, and laminar destination of neocortical neurons. Cereb Cortex 15:1343-1355.

-Verney C, Takahashi T, Bhide PG, Nowakowski RS, Caviness VS Jr (2000): Independent controls for neocortical neuron production and histogenetic cell death. Dev Neurosci 22: 125-138.

Vogt C (1895): Mémoire sur les microcéphales ou hommes-singes. Paris. von Economo C, Koskinas GN (1925): Die Cytoarchitektonik der Hirnrinde des erwachsenen Menschen. Berlin, Springer.

von Koelliker A (1896): Handbuch der Gewebelehre des Menschen. Leipzig, Engelmann.

Wiesel TN (1982): Postnatal development of the visual cortex and the influence of environment. Nature 299:583-591.

Woolsey T, Wann J (1976): Area changes in mouse cortical barrels following vibrissal damage at different postnatal ages. J Comp Neurol 170:53-66.
Woolsey TA, van der Loos H (1970): The structural organization of layer IV in the somatosensory region (SI) of mouse cerebral cortex. Brain Res 17:205-242.

Yun K, Mantani A, Garel S, Rubenstein J, Israel MA (2004): Id4 regulates neural progenitor proliferation and differentiation in vivo. Development 131:5441-5448.

Zilles K (1990): Cortex; in Paxinos G (ed): The Human Nervous System. New York, Academic Press, pp 757-802. 